\title{
Development and Progress as Historical Phenomena in Tanzania: "Maendeleo? We Had That in the Past"
}

\author{
Robert M. Ahearne
}

\begin{abstract}
Academic discussions of development continue to grow, yet critical engagements with communities affected by development interventions remain limited. Drawing from life history interviews conducted in southern Tanzania, this article details the varied experiences of development interventions among older people and how these affect broader understandings of progress. Many juxtapose their negative views of ujamaa villagization with more positive recollections of previous interventions (especially the Groundnut Scheme), which are infused with what is described here as "development nostalgia." Perceptions of the past clearly inform the social, political, and economic aspirations forwarded today, with the richness of the constructed narratives adding further nuance to existing depictions of Tanzanian historiography.
\end{abstract}

Much of the academic work on the subject of development tends to focus on the present and the future, despite the fact that experiences from the past are crucial in shaping localized understandings of progress (Crewe \& Harrison 1998). Drawing from in-depth fieldwork in southern Tanzania, this article aims to address a point raised twenty years ago by Jonathan Crush: that "we still do not know enough about the global, regional and especially local historical geography of development" (1995:8-9). Conventional histories of Tanzania, and of Tanzanian development, tend to offer teleological versions of the past, reflecting Kelly Askew's (2006) threefold division of the presocialist, socialist, and postsocialist eras in recent Tanzanian history. Periodizations of history, of course, are "utterly relative constructs, [which] reflect their own sense of the 'style' of the historical past" (Toohey 2003:10). Nevertheless this three-part division is the general way in which Tanzanian history is typically understood. And with the one caveat that it is necessary to consider how these periods are "materially, ideologically and rhetorically related to each other" (Askew 2006:16), this general approach does seem reasonable, given that thirty years have elapsed since the formal conclusion of socialism in Tanzania with the first Structural Adjustment Program introduced in 1986, following roughly a quarter of a century with Julius Nyerere as president. However, those who have lived through these times tend not to carve up the past in such a manner, and as Lawi (2005) asserts, nationalist readings of Tanzanian history which focus on these and other milestones often reflect largely urban and elite experiences as opposed to the lives of the rural majority. Ellis (2002), for example, questions whether independence is a sensible historical marker outside of urban areas across much of Africa,

Indeed, from the perspective of the wazee (i.e., elders), whose narratives of development are at the centre of this research, the 1967 Arusha Declaration can be regarded as more significant than national independence as a turning point in Tanzanian historiography (see Havnevik 1993; Jennings 2003). ${ }^{1}$ The Arusha Declaration brought about fundamental changes in the structure of the relatively newly independent country and instigated the twin processes of economic nationalization and rural collectivization (especially in the guise of what has become known as "villagization") that materially changed their lives. With regard to the latter process, negative memories of the 1970s dominated many of the discussions that I had with wazee in southern Tanzania, who often argued that the conditions of everyday life have "gone backwards" (-rudi nyuma) since this process was instituted. By contrast, many see the "past"i.e., the period before the state-led process of ujamaa villagization — as a time of infrastructural 
improvements, employment opportunities, cheaper commodities, and stability: as a time, that is, more closely associated with progress than the present. This point of view serves to inform contemporary readings of maendeleo (a close Swahili equivalent of "development"), while also illuminating broader discussions of Tanzanian historiography.

The article begins with a discussion of the research project and fieldwork sites on which it is based and then moves on to a discussion of maendeleo. It addresses the notion of nostalgia specifically in terms of experiences of material advancement in "the past" and how this informs perceptions of development. It then outlines the postcolonial formation of ujamaa villages and examines the impact of this massive government-led experiment in social reorganization. This is then placed alongside some of the more favourable views that are held regarding the opportunities and life chances - and particularly the material advancements - that are associated with the period traversing independence and prior to villagization. While exploitative colonial relations were highlighted by informants during the fieldwork study, these were seen as preferable to the apparent ostracism of the Mtwara region prior to the infamous Groundnut Scheme and following the pernicious impact of villagization. This article reflects on contemporary forms of "development nostalgia" in southern Tanzania, in which perceptions of "the past" inform social, political, and economic aspirations of wazee, and it seeks to add to existing discussions of Tanzanian historiography.

\section{The Research Process and Fieldwork Sites}

This research project was the outcome of a number of conversations regarding maendeleo in the coastal village of Mikindani, situated twelve kilometres outside of the regional capital of Mtwara. This village was the main administrative centre in southern Tanganyika until the late 1940s, when it was replaced by the newly established town of Mtwara, built as part of the colonial Groundnut Scheme and subsequently connected to Nachingwea in the interior by a railway that passed through Mikindani. The construction of the Mtwara port and of the railway dramatically increased wage labour during the late 1940s and early 1950s (Rizzo 2006). While not an officially designated ujamaa village in the 1970s, Mikindani was affected by migration flows across Mtwara region before, during, and after the villagization processes were enacted in the 1970s (Lal 2010) and has also witnessed the establishment of a number of European NGOs espousing development over the past fifteen years.

The other fieldwork site, Dihimba, is also on the railway that was established to the interior (but has not run since the 1950s). Dihimba was more directly affected by villagization processes, given that the ujamaa village of Mpondomo was established within the existing parameters of Dihimba in 1972. It is around forty kilometres inland from Mikindani and is remote in comparison; it has minimal phone reception and no electricity, and is accessible only via an unpaved road with limited access by public transport. Dihimba had a population of around four thousand at the time of the research, while Mikindani had around eleven thousand residents. Cashew nuts are the principal cash crop, and while agriculture remains the main source of employment in each village, many in Mikindani also depend on fishing for their livelihoods (URT 2009). These fieldwork sites are not meant to be representative of the entire Mtwara region, yet I felt that they were both sufficiently similar, and also different enough, to 
facilitate a productive comparison.

Socialist villagization processes affected southern Tanzania more than any other area during the 1970s (Killian 2003) and this, coupled with the widely held perception that Mtwara has been deliberately marginalized by central government (Seppälä \& Koda 1998), made the region an ideal choice for this research project. This article emanated from an original intention to construct life history narratives (Ahearne 2011) that detail historical processes that are simultaneously regional, national, and global, and it is through these accounts that a strong sense of development nostalgia emerges. The decision to focus on wazee was partly informed by postcolonial theories and reflects a desire to foreground the voices of subalterns who are often marginalized, particularly concerning interpretations of development (Reef 2008; Spivak 1999) and projects established in the name thereof. Older people do not, however, represent a homogeneous group, and participants ranged from sixty-five to ninety years old, with some generational differences witnessed when it came to memories of wage labor in the late-colonial period and in terms of the recollections of villagization. Striking a balance in the number of interviewees conducted with women and men was also difficult, but of the sixty semistructured interviews drawn from in the discussion here, twenty-four were conducted with women while the eight focus groups were mixed. The fieldwork took place across every ward of both villages during a pre-fieldwork study in 2008 (two months), with the longer period of study taking place in 2009 and 2010 (and lasting for ten months in total). Beyond this, some conversations from a later research trip in 2012 (over the course of three months) were drawn on, alongside a great deal of participant observation. All interviews were conducted in Swahili and recorded, and then transcribed and translated as soon as possible after completion.

\section{Development, Nostalgia, and "Development Nostalgia"}

Development is a notoriously difficult word to translate, and the close Kiswahili equivalent of maendeleo-rooted in the verb -endelea (to go forward) and reflecting an etymological connection with progress - is employed here. Maendeleo is a term that has elsewhere been seen as highly relevant to localized readings of progress in Tanzania (Marsland 2007). Much like the word development, it is a crucially important part of the postcolonial political lexicon while remaining highly contested. While it is "widely used in East Africa and often denotes similar ideas about development and progress, maendeleo is not a unitary, fixed discourse over time and space, but rather is mutable, contingent, and open to local reinterpretation and appropriation" (Mercer 2002:111). Maendeleo resonates with the socialist political and economic thought of Julius Nyerere and is related to terms like kujitegemea (self-reliance), kushirikiana (cooperation), and umoja (unity), all of which figure heavily in the ideology of ujamaa ("familyhood") (Harrison 2008; Hunter 2008). As Green (2000) explains further, the term is often used to refer to interventions by external agents (especially in relation to projects established by NGOs) and small-scale private investments alike. Today less emphasis tends to be placed on the role that the government ought to play in development, although the apparent absence of development is still blamed on a state unwilling to support its (rural) constituents. For wazee in particular, the largely negative outcomes of villagization processes have led many to challenge the appropriateness of collectivization and have had a significant impact on their perceptions of development. For these elders, notions of maendeleo are connected to what are 
viewed as failed state interventions, which "left people poorer and more bereft than they had been prior to villagization" (Green 2000:77).

Many development professionals now tend to prioritize individual, small-scale material advancement over collective benefit, a new emphasis which, as Pitcher and Askew (2006:11) thoughtfully remind us, tends to emphasize the "self" in self-reliance. It is clear that small-scale material improvements in people's lives are often conceived of as development in Tanzania, with "houses made of udongo (mud-sticks-fronds with a thatched roof)" often deemed symbolic of a lack of progress, while owning "a matofali house (a stronger structure made of permanent bricks with corrugated iron sheets) is a clear sign that one has advanced in life" (Kamat 2008:372). Such changes do have practical significance, in terms of the ability to store grain during wet seasons (Da Corta \& Price 2009), but it is apparent that material improvements to housing also play a more public, symbolic role as representations of progress across many parts of eastern and southern Africa (Ferguson 2006; Morton 2007). This is reflected by the informant below who, like many others, stressed the connection between his perception of development and visible evidence (and the lack thereof) of material advancement: "You see my house? There are big holes here, no doors, and a leaking roof. I don't like it but they are there because I don't have development" (M. Kidume, interview, Mikindani, April 28, 2009). According to another informant, "Development means to succeed, to prosper. . . . If so, I will improve my house or have a big farm with cows. But for us there is nothing" (F. Selemani, interview, Mikindani, October 9, 2009).

These comments echo a notion that was referred to critically in a number of interviews of "maendeleo ya mtu binafsi," or "personal/self(ish) development," which Green (2000) found to be prevalent elsewhere in southern Tanzania as well. This concern is linked to widespread criticism of the communal approach to development and especially agriculture in the 1970s. Agriculture remains the main source of employment in the Mtwara region, with cashew nuts crucial to the regional economy and representing the main opportunity for increased individual wealth (Mashindano et al. 2011). Nevertheless, the absence of promised government support in the form of subsidies, and the unavailability of affordable pesticides, fertilizers, and highquality farming tools reduces the possibility of extracting the greatest possible value and provokes further resentment toward the government. This antipathy toward the government, and its apparent failure to support rural peoples in southern Tanzania, is evident in the argument that things have effectively gone backwards (- rudi nyuma) since villagization.

Nostalgic representations of "the past" and conditions of life prior to this process are also exceptionally common on the part of women and men who associate "the past," the time of their youth, with maendeleo. It is of course necessary, as Sanders (2008) points out, to acknowledge that difficulties arise when scholars attempt to specify the precise relations between past and present, and that reliance on binaries of "then and now" within anthropology often tend to valorize the past and circumscribe the possibilities of the present. Other scholars have argued as well that colonial or imperial nostalgia is a particularly Western issue (Rosaldo 1989), especially within the discipline of anthropology (Ferguson 2006). This article does not suggest that a quantifiable rupture exists between past and present, but only that such perceptions exist among many elders and are worth examining; as Bissell argues, instead of provoking reactions of "embarrassment or distaste," (colonial) nostalgia ought to be considered 
along with other cultural phenomena in order to uncover the specific "social and political desires [that] postcolonial Africans [are] giving voice to when they speak well of the colonial past" (2005:217). Moreover, nostalgia represents "a cultural practice, not a given content; its forms, meanings, and effects shift with the context - it depends on where the speaker stands in the landscape of the present. ... [It is] an essential narrative function of language that orders events temporally and dramatizes them" (Stewart 1998:227). Ferguson's (1999) analysis of workers on the Zambian Copperbelt and their association of progress with past practices and experiences is a seminal work in this regard. Another important study is Piot's (2010) ethnographic account of Togo since the conclusion of the Cold War, especially his concept of "nostalgia for the future." Effectively reversing the common assertion that nostalgia relates only to the past, he demonstrates that many Togolese now express nostalgia for what is yet to be seen, an uncertain and elusive future that is marked by the possibilities presented by "a thousand development initiatives that hail youth and leave elders behind" (2010:20). It is important, then, to consider the ways in which nostalgia relates not only to the past but also to aspirations for the future and how the very "capacity to aspire," in the words of Appadurai (2004), is culturally contingent and directly informed by life experiences.

This study, therefore, looks at nostalgia as a cultural practice that allows for the expression of certain social and political desires and material aspirations that serve to complicate localized and national narratives of development and history in Tanzania. While backward looking, nostalgia nevertheless demonstrates a desire for a better future. It is of course relatively common for older people to view the past as a more stable and fixed time than the present and to experience the present as marked by a general sense of "longing and loss" (Bissell 2005:225), "the feeling that everyday life no longer has its taken-for-grantedness" (Werbner 1998:1). As one informant stated, "things [in Mtwara] did not change in the past, we just lived. We had a government but we knew nothing about that, we didn't know about these things until the British left and the government forced all of us to move" (M. Masoudi, interview, Dihimba, June 8, 2009). In the case of wazee in Mtwara, however, this kind of generalized nostalgia is also connected to a series of specific historical experiences - such as villagization - that created a clear break with the past and generated huge and often unrealistic expectations. The fact that these have not been met has therefore led many to invoke past experiences of intervention and processes of change as clearer indicators of development.

\section{Experiencing Ujamaa: "They Destroyed Our Farms to Build Something Called the Nation"}

Among wazee in Mikindani and Dihimba, the perceived stability that was disrupted by villagization was associated with the time traversing the late colonial and early postcolonial periods (roughly the 1940s to the 1970s), and particularly with some of the material transformations brought about by late colonial development policy. These changes were the outcome, at least in part, of the Colonial Development and Welfare Act of 1940, which brought about salutary investment in Britain's African colonies (Van Beusekom \& Hodgson 2000) elsewhere described as akin to a "second colonial occupation" (Hodge 2007). In emphasizing the continuities rather than the differences between these two supposedly distinct eras, many older Mtwarans are aligned with a number of scholars who argue against perceived dichotomies 
that seek to separate colonial and postcolonial eras (see, e.g., Abrahamsen 2000; Cooper 1997; Jennings 2003; Van Beusekom \& Hodgson 2000). While Ranger (1996:273) rightly challenges the "disconcerting preference" among many contemporary Africans for the "apparent authoritarian stabilities and disciplines of colonial systems that were much less coherent, simple and lucid than such dualism suggests" - the matter of perceived colonial stabilities does not need to be emphasized here. Of most significance here are the regular references of the wazee to "the past" as a time prior to the social and economic ruptures associated with forced resettlement.

The 1967 Arusha Declaration of the Tanzania African National Union (TANU) defined many of the socialist policies of at least the following decade and therefore represents an extremely significant document, and moment, in Tanzanian history (see Jennings 2008). Along with the major program of nationalization that it initiated, one of the principal outcomes was villagization, the massive social experiment emanating from central government (and espoused in Nyerere's writings) which effectively sought to restructure society and reorganize rural life through the voluntary migration of rural people from small villages into new and more sizeable communal villages. The process intensified during the 1970s, which saw a dramatic increase in the size and population of many existing places (with Dihimba one such example), alongside the formation of new ujamaa villages. One of the guiding principles of villagization was that communal farming would improve agricultural productivity and would therefore guarantee long-term food security and self-sufficiency. Another assumption was that an otherwise unreachable rural population must be relocated in order to receive "services, such as schools, safe water, and health facilities" (Schneider 2007:12).

Migration to ujamaa villages was initially voluntary. Nyerere (1973) declared that forcing people to move would not be countenanced by the state since it undermined one of the fundamental principles of villagization - that it was to be a voluntary process. Nevertheless, when only 15 percent of the total population chose to resettle between 1969 and 1973, TANU, in what was then a constitutionally inscribed one-party state (Brennan 2006), reversed its position. According to one informant, at first only those without material resources moved voluntarily, since promised future services did not provide enough of an incentive to leave behind farms and houses: "At the start people decided whether to go. Many stayed with their wealth; buildings, cashew nut trees, coconut trees and mango trees. People who had nothing went to cooperate, to build, and to live in ujamaa villages. Then the government forced everyone to go" (A. Ali, interview, Mikindani, February 10, 2010). In 1973 TANU decreed that "to live in villages is an order" (Bernstein 1981:45), rapidly transforming voluntary migration "into mass resettlement, ujamaa into villagization" (Jennings 2002:511-12). Mamdani (1996:176) adds that increased authoritarianism in Tanzania from the late 1960s onward was in fact akin to "decentralized despotism," reflecting the continuities of colonial modes of rule within postcolonial structures of power (see also Jennings 2008).

Today wazee in Mikindani and Dihimba consistently argue that migration was involuntary. Many also recall it as a brutal process involving violent removal from their land and the destruction of property by the police and security services; according to one informant, "people were moved by force, the soldiers came, they came to worry the people, and they were taken, all of their things were destroyed or put in a truck" (A. H. Barakati, interview, Dihimba, May 
$8,2009)$. This informant made it clear that she was not opposed to the principle of rural collectivization per se, although being forced to move to Dihimba and witnessing the destruction of family crops by security forces certainly informed her viewpoint. For many people, in fact, villagization was a de facto "nationalization of poverty" (Green 2000). One informant directly blamed former President Nyerere for "destroy[ing] our farms and the houses of people who were living in the wilderness, forcing them to come together to build something that he called the nation" (H. Musa, interview, Mikindani, July 22, 2009).

It is possible that the most harmful and pernicious methods of forced relocation were the actions of "over-zealous officials" (Jennings 2002:513). Not all of the sixty interviewees whose narratives are drawn from in this article recalled villagization with such hostility, confirming Lal's (2010:14-15) finding in other parts of Mtwara that while some do recall being forcibly loaded onto vehicles by soldiers "threatening to burn or destroy their homes and property ... [,] others merely recall a benign order to relocate." The views presented here, therefore, tend to favour Schneider's (2007) contention that villagization, far from a monolithic form of national scientific socialism (see, e.g., Scott 1998), was far less centrally planned and more arbitrary than had previously been assumed. Nevertheless, the first-hand experiences of villagization certainly had a profound and lasting impact on many of the wazee, especially those who recall being forced to relocate and who generally view the destruction of private property as central to villagization.

Their views are also informed, undoubtedly, by the actual effects of villagization. Despite the objective of food security, what followed was a national food crisis. Once the migratory process became compulsory, the production of food by the newly resettled rural majority was reduced dramatically (Wembah-Rashid 1998), and the country went from being one of the largest exporters of agricultural products in Africa to the largest importer by 1976 (Maier 1998). Acute food shortages were also experienced across the country between 1973 and 1976, lasting in some regions to the 1980s (Ergas 1980). One of the reasons for the dramatic reduction in food production, according to one informant, was a lack of incentives: "People didn't work hard and prepare new farms quickly because they were scared these would be destroyed like the old farms. The village chairman told us not to plant more than five trees in the ujamaa village because we might be moved again" (M. Musa, interview, Dihimba, January 29, 2010). An additional factor was the difficulty of tending to "old farms," which after resettlement were often located some distance from where rural peoples lived. At the same time, the increasing material limitations of the Tanzanian state meant that the provision of social services was not nearly as widespread as had been promised (Lal 2010). For the most part, those who moved (whether long or short distances) did not experience the level of social service provision that was supposedly guaranteed within national(ist) political rhetoric. Even today, while such services are still relevant in contemporary conceptions of social development, it is widely argued within both in Mikindani and Dihimba that an increasing number of school buildings, hospitals, and health facilities are irrelevant given the lack of affordable medicine and doctors, the poor training of low paid and unmotivated teachers, and the shortages of necessary resources in schools. ${ }^{2}$

It seems clear, then, that to the wazee of the Mtwara region the negative economic impact of villagization, coupled with the psychological trauma of forced resettlement, represents a 
significant occurrence in Tanzanian history. In spite of the fact that Mtwara, in terms of area, was the third smallest of the twenty-six regions of mainland Tanzania (as defined in 1976), more than one-eighth of all ujamaa villages were created in that region. This leads Killian (2003) to suggest that Mtwara (alongside Lindi, which had the second highest number of ujamaa villages) was something of a testing ground for this government experiment in social reorganization, which clearly destabilized the everyday lives of many in the rural majority. It is not surprising, therefore, that villagization is recounted as a significant historical "moment" around which the life narratives of many older people in Mtwara region are structured. They in fact tended to refer more to these memories than they did, for example, to the Arusha Declaration that precipitated villagization or even to the milestone of national independencean observation also made by Schneider (2007) in another part of Tanzania. Compared to the lived experiences of national policies like villagization, independence does not seem to hold a particularly significant place in these "life narratives": "Tanganyika became Tanzania and our flag changed, Elizabeth left and Nyerere arrived. The leaders knew about these changes but nothing changed for me, I've always been a farmer" (S. Mohammedi, interview, Dihimba, April 22, 2009). Here it is useful to recall the argument posed by Ellis (2002:6), that while sovereign independence was politically unstoppable across much of Africa during the late 1950s and into the early 1960s, dividing African histories around this marker is problematic since it "was not a universal milestone, but is in reality a concept largely derived from studies of Europe and North America." There is a tendency, in other words, for researchers to impose their own sense of historical periodizations rather than focusing on, and drawing out, those of the "researched" (see Toohey 2003). As such, independence does not seem to be a defining moment for all Tanzanians, and it might be argued that in this context, and perhaps in other African countries, independence was something of an elitist urban phenomenon. Those older people in Mtwara who do make reference to uhuru (taken to mean independence here) either associate it directly with forced resettlement or view it as something of an enigma and filled with a multitude of undelivered expectations.

Among the people interviewed there was a clear understanding of some of the benefits of the economic liberalization that took place after villagization, often explained as the outcome of President Mwinyi's having “opened the borders" to imports. Yet most of the new goods first made available during the $1980 \mathrm{~s}$ - for example, fabric, shoes, and televisions - are not affordable to cash-poor older people, an argument particularly made by women, who tend to control household budgets: "We had enough money in the past, but now 100 shillings [US\$0.05] is not enough to buy anything" (H. Selemani, interview, Mikindani, November 25, 2009). The sorts of commodities (clothes, sugar, rice, tea, etc.) that were affordable in "the past" have seen considerable price increases as an outcome of liberalization (Bryceson 2002) and are now also in short supply (see Bernstein 1981; Ergas 1980). At the same time, the destruction of "traditional" support networks following forced resettlement means that shortages that previously had been absorbed within the community now burdened individuals and families. The emergence of NGOs and small-scale development projects from outside is not seen to have ameliorated these worsening conditions, a view that is informed by past experiences of "outside intervention" and the short-term creation of jobs in the region during the latter stages of the colonial period. Today the general perception is that only those who can obtain employment benefit from these projects, rather than project recipients themselves: "NGOs? .. . The only people from Mikindani that are involved are the workers, who benefit a 
little. . . Most of us get nothing from them" (A. Shaibu, interview, Mikindani, June 29, 2009).

Some of the complaints in Mtwara about the unfulfilled promises of uhuru, ujamaa, and villagization bought up perceptions of a particularly geographical bias: the lack of political will to provide necessary services in the south because Tanzanian politics "is dominated by those from the north" (S. A. Likolo, interview, Mikindani, July 25, 2012). ${ }^{3}$ Many agreed that this remains the case with more recent failures, for example, to deliver promised cashew nut subsidies or to complete the road to Dar-es-Salaam. National leaders are aware of what has been described as the belief in a "hidden agenda" (Wembah-Rashid 1998) working against southern Tanzania and are alarmed by a particular trend among southerners, which was indeed displayed by many informants, to identify themselves as Tanganyikan rather than Tanzanian. Former President Kikwete himself felt the need to challenge this practice in a 2009 public speech: "We are now done with the tale that people living in southern parts of the country were still Tanganyikans and those living in the northern part were real Tanzanians, that is now history" (The Citizen 2009).

Yet among all of the narratives of complaint and disappointment expressed by many informants, the one positive memory of a development project that fulfilled its promises and stands out was a late colonial project: the Groundnut Scheme that was carried out in southern Tanganyika from the late 1940s and to the early 1950s. Almost without exception, this infrastructure project is regarded as a significant symbol of development from the past, one that brought stability, wage employment, clear material advancements, and technological improvements and is recalled with particular nostalgia by informants who had direct experience working on the Scheme itself or on the ancillary railroad project.

\section{The Formative Experience of the Groundnut Scheme}

The initiation of the Groundnut Scheme in 1947 in southern Tanganyika was part of larger changes in the management of African colonies in the period following World War II by the governments of both Britain and France, which sent "waves of experts" to reinvigorate colonialism by trans-forming farming and working methods and increasing the focus on education and welfare (Cooper 1997). The project was part of a broader shift in "late colonial development agendas" which, as Van Beusekom and Hodgson argue (2000:31), were "neither hegemonic nor unchanging ... [and were] tied to both global changes and local realities of the late colonial era." The election of an interventionist Labour government in Britain following the war led to a greatly expanded welfare state domestically and saw the emergence of largescale colonial development projects, exemplified by the Groundnut Scheme. The Scheme was a politically expedient project designed to produce groundnuts (peanuts) which would then be turned into food oils in order to challenge the U.S. monopoly over these products and reduce the cost for the British working class (Myddelton 2007). Vast tracts of land in the interior of southern Tanzania (around Nachingwea in Lindi region) were demarcated as huge farms for the production of groundnuts and a train line was built to connect these to the newly built port at Mtwara in preparation for the transport of the abundant crop.

Rizzo (2006) argues that the Scheme and its related projects brought "a big boom to trade 
in the little township of (Old) Mikindani. . . . Despite a disappointing agricultural season, the local population seemed to be contented with plenty of money available, the effect of the unlimited demands for labor of all sorts" (2006:217). Large numbers of people were employed directly as part of the Groundnut Scheme or as part of related projects resulting from the increased investment that followed the Colonial Development and Welfare Act of 1940. All of these projects led to significant labor migration into the region, where "men circulated to work at sisal plantations in Mikindani and what became the town of Mtwara on the coast, on smaller private farms in the interior as hired labourers, or on infrastructure projects catalyzed by the Groundnut Scheme ...” (Lal 2010:10).

By 1951, however, the Groundnut Scheme was abandoned. In the end, intense efforts to seed the crop meant that more groundnuts were imported into Tanganyika than were produced by the Scheme, which is now widely analyzed in the scholarly literature as a massive failure (see Myddelton 2007). According to the colonial authorities, a major problem was the acute shortage of consistently available unskilled labourers, a problem that was officially attributed to an inherent laziness on the part of local workers. In fact, the real problem was that the project mostly employed seasonal farmers on a casual basis who chose to farm land or to harvest crops when this work proved more lucrative (Rizzo 2006). Although an analysis of the ethnocentric perspective of the British - who labelled as "laziness" behaviour that could more rightly be described as an assertion of personal agency - is clearly beyond the scope of this article, an instructive comparison might be made between the Groundnut Scheme and the Maasai Development Project (also adopted in 1951), in which "the very willingness of Maasai to help finance local development projects and diversify their sources of income seems only to have reinforced officials' vision of them as intransigent traditionalists who had to be compelled to help themselves" (Berry 2000;130; see also Hodgson 2000). The behaviour of the British in this case may also be compared to that of the French Office Du Niger, which did over time accommodate itself to the existing practices of farmers (see Van Beusekom 2000).

It is also ironic that while the Scheme may have failed in relation to the stated objectives of the British, the experiences of those who participated, along with the technological improvements brought by the Scheme and the degree of personal agency it involved, are recalled fondly by many wazee in Mtwara. The construction of a railroad and the introduction of a train as part of the colonial project was one of the most common referents of development among wazee in Mikindani and Dihimba, juxtaposed with the contemporary reliance on expensive "broken buses" running on unpaved roads. The crumbling transport infrastructure in southern Tanzania today embodies a clear sign of regression, and while the train that was introduced as part of the Scheme only ran for a handful of years during the 1940s and 1950s, many reminisce over this cheap and effective means of transport: "I was happy because I used it to travel, as did many people. The train was like development for us, we could travel long distances cheaply and quickly, but we cannot do so anymore. The train was good, much better than what we have now" (S. H. Sululu, interview, Dihimba, September 8, 2009).

Opportunities for work in "the past," often as part of the Groundnut Scheme and ancillary projects, are also remembered fondly (especially by men), and many wazee view a short period in the latter stages of the colonial era as a time when the historical ostracism or maltreatment of southern Tanzania was effectively reversed (only to be reinstated later). A variety of jobs 
were created as part of the Groundnut Scheme, or on one of several sisal plantations in the region: "We collected soil and stones for the railway, or worked on the sisal estate. We could choose. . . Companies were coming to Mtwara with different machines, I used to go to Mtwara to work, but the jobs have gone" (M. Hamisi, interview, Mikindani, March 4, 2010). This interviewee directly compared his decision to move to Mtwara for work in the late 1940s with the experience of being forced to move from Liwoye to Mikindani in the 1970s, emphasizing the personal agency in the earlier period as opposed to his powerlessness during villagization. Many saw the potential to procure casual employment as a clear benefit, both in Dihimba and in Mikindani, and as Rizzo (2006) points out, the Scheme created a localized economic boom. Elsewhere Rizzo (2009) demonstrates that opportunities for street hawking presented themselves to the most entrepreneurial and economically savvy in the interior at Nachingwea, moving us beyond assumptions that such a livelihood is an exclusively recent, urban phenomenon across Africa (see also Klaeger 2013).

Regular references to the abundance of work in "the past," then, draw from a trope of nostalgia and offer a reference point against which the absence of paid work today is criticized. For some informants in and around Mtwara town, the Scheme had a long-term impact on their lives, even after it formally concluded. One man, who acknowledged that his good fortune derived partly from the fact that his uncle worked in the colonial service, said

My first work was building the train line. From 1947 I built the port [Mtwara] until it was finished in 1956. . . I worked again after some years and in 1960 I performed kazi ya mikono [manual labour] at the port. After 1967 I was employed there again, at the port as a winch operator. I continued with that work until I retired. (A. Adeni, interview, Mikindani, May 15, 2009)

He also expressed optimism for future industrialization in light of recent gas discoveries in the region. Nevertheless, even these positive representations of his previous working life and his hopes for the future were juxta-posed with vehement opposition to villagization because of the economic suffering of his family and what he saw as clear government deception concerning service provision.

Many wazee do acknowledge that the wages paid in colonial times were low and exploitative. "Workers were getting one shilling a day for hard labor, which was not enough," said one interviewee, a forestry expert trained in Arusha who organized a number of strikes over pay discrepancies between Tanganyikan and British workers in the 1950s and was eventually resettled in Mbinya (near to the Malawian border) by the colonial government (Mzee Nguruwe, interview, Mikindani, April 10, 2009). Nevertheless, the predominant view remains that despite the exploitative economic relations of the late colonial period, the guaranteed work was preferable to farming, which was the only alternative at the time and remains the main source of food and income generation today. While somewhat beyond the scope of this article, it is notable that like the informant quoted above, a number of those involved in this research project expressed a degree of optimism regarding the recent discoveries of offshore natural gas in the Mtwara region and framed this in light of their own past experience of major overseas investment and infrastructure expenditure. It can be argued that this, at least to some extent, reflects the sort of future-oriented nostalgia outlined by Piot 
(2010) - albeit in this instance a nostalgia that is informed in no small part by a brief but incredibly formative period of wage labor and perceived technological advancement.

\section{Concluding Comments: Development Nostalgia and Life Narratives}

In whichever ways wazee conceive of development, they generally see it as inaccessible or largely unavailable in southern Tanzania today, just as it has been since the formation of ujamaa villages: "Maendeleo? We had that in the past . ..," said one informant. "We wanted village development, but it [villagization] failed, and if you compare this time to the past, in the colonial era there was development. It was not a great time, but we did not bring development through ujamaa villages" (A. Ahmadi Chap., interview, Dihimba, July 12, 2009). This article contrasts the tendency within mainstream development literature to focus solely on the future (e.g., Crush 1995; Kothari 2005) with the complex reality that development can be viewed in terms of nostalgic glimpses into "the past." This is exemplified by many wazee in Tanzania who have nostalgic feelings about development projects of the past, even ones, like the Groundnut Scheme, that are widely analyzed in the academic literature as abject failures. While their "capacity to aspire" (Appadurai 2004) has been diminished, what remains is a sense of nostalgia that functions as a kind of "aspiration without possibility, deploying sensibilities and values drawn from the past in the context of current struggles" (Bissell 2005:226). In focusing on these representations of the past, this article calls for and contributes to richer and more nuanced accounts of Tanzanian historiography.

Wazee often argue that their "time has passed," and it is important to acknowledge that the focus on this specific group is likely to result in a degree of nostalgia. Nevertheless, the characterization of "the past" as a time of low prices, clear technological advancement (especially in terms of the infrastructural changes brought about by the Groundnut Scheme), stability, and guaranteed employment, gives older people a benchmark against which to measure their contemporary situation and to categorize their experience of other historical processes. Many participants emphasized the significance of the infrastructural development of the 1950s, while those who had worked in the late colonial period as wage labourers (mostly men) were particularly positive and saw this experience as greatly preferable to forced migration and the failure to provide promised government services. Many of the women interviewed also echoed this sentiment, but made more direct reference to the prohibitively high prices brought about by the massive underproduction of food and by economic liberalization during the 1980s. It may be that exploitation by global capitalism is seen as contributing to ostracism, as argued by Katz (2004) in relation to South Sudan and similar to what Ferguson (1999) sees as "abjection" in Zambia following the collapse of the copper mining industry in the 1970 s.

In light of this research, it will be interesting to see whether the expectations already generated by the recent discovery of large reserves of natural gas off the coast of southern Tanzania will ever be met. Further fieldwork that I have conducted in Mtwara (see Ahearne 2013) suggests otherwise, however, and recent protests in Mtwara over the supposedly unequal distribution of revenues generated from natural gas seem to frame this as part of the continued mistreatment of the south. The radical and repeated narratives from protestors of "gesi ibaki au 
tugawane nchi" ("the gas [and related wealth] should remain here or we must divide the country") call for greater regional benefits or outright secession. In terms of current attitudes, however, the generational differences in regard to notions of development are stark. The younger generations do not want to feel exploited, while their elders perhaps feel that brief experiences of sacrifice for the sake of shared goals for the future are preferable to ostracism and continued marginalization (see Ahearne 2011). ${ }^{44}$ The disappointments of villagization and of promises that have not been fulfilled foments a strong sense of nostalgia and provides some of the reasons that maendeleo is so often understood as a thing of "the past."

\section{References}

\section{Interviews}

Ahmadi, Shaibu, age 68, farmer and driver, Mikindani, June 29, 2009. Aisha, Ali, age 65, farmer and sisal cutter, Mikindani, February 10, 2010.

Ali Ahmadi Chap, Chap, age 80, Mozambican (lived in Dihimba since the civil war), retired fisherman, Dihimba, July 12, 2009.

Ali, Adeni, age 80, port worker and farmer, Mikindani, May 15, 2009.

Asha Hassani, Barakati, age 68, farmer (whose family was forced to move during villagization), Dihimba, May 8, 2009.

Fikiri, Selemani, age 80-85, farmer, Mikindani, October 9, 2009.

Hamisi, Musa, age 75, worked on railway construction, a former CCM ward executive and an entrepreneur, Mikindani, July 22, 2009.

Hadija, Selemani, age 80, farmer and shop worker, Mikindani, November 25, 2009.

Mohammedi, Kidume, age 85, wage labourer on railway line for the Groundnut Scheme, April 24, 2009.

Mohammedi, Hamisi, age 85-90, tool maker, retired farmer, and wage labourer on the Groundnut Scheme, Mikindani, March 4, 2010.

Mohammed, Masoudi, age 70, farmer, former CCM village chairman, railway builder and port worker, Dihimba, June 8, 2009.

Mohammedi, Musa, age 65-70, carpenter and farmer (son of a railway worker for the Groundnut Scheme), Dihimba, January 29, 2010.

Mzee, Nguruwe (pseudonym), age 73, forestry expert, gardener, and NGO translator, Mikindani, April 10, 2009.

Salumu Hassan, Sululu, age 72, village chairman, retired farmer, worked on building the railway, Dihimba, September 8, 2009.

Selemani Abdalla, Likolo, age 66, CCM ward chairman, cashew nut farmer and former fisherman, Mikindani, July 25, 2012.

Shuwea, Mohammedi, age 90, farmer and migrant from Lindi (moved to live with family during villagization), Dihimba, April 22, 2009.

\section{Books and Articles}

Abrahamsen, Rita. 2003. "African Studies and the Postcolonial Challenge." African Affairs 102: 189-210. 
Ahearne, Robert M. 2011. "Understanding Contemporary Development: Life Narratives of Intervention." PhD. diss., University of Manchester.

2013. "The Untold Story of Tanzania's Resource Curse." Think Africa Press. http://thinkafricapress.com.

2014. "'Le développement? C'est du passé'. Une lecture historique des récits du progrès dans la Tanzanie du Sud." Politique Africaine 135: 23-46.

Appadurai, Arjun. 2004. "The Capacity to Aspire: Culture and the Terms of Recognition." In Culture and Public Action, edited by Vijayvendra Rao and Michael Walton, 59-84. Stanford, Calif.: Stanford University Press.

Askew, Kelly M. 2006. "Sung and Unsung: Musical Reflections on Tanzanian Postsocialisms." Africa 76 (1): 15-43.

Bernstein, Henry. 1981. "Notes on State and Peasantry: The Tanzanian Case." Review of African Political Economy 8 (21): 44-62.

Berry, Sara. 2000. “Afterword.” Journal of African History 41: 127-30.

Bissell, William C. 2005. "Engaging Colonial Nostalgia.” Cultural Anthropology 20 (2): 21548.

Brennan, James R. 2006. "Blood Enemies: Exploitation and Urban Citizenship in the Nationalist Political Thought of Tanzania, 1958-1975." Journal of African History 47: 389-413.

Bryceson, Deborah H. 2002. “The Scramble in Africa." World Development 30 (5): 725-39.

The Citizen (Tanzania). 2009. "Tanzania: Kikwete-Beware of Foreign Land Grabbers." http://allafrica.com.

Cooper, Frederick. 1997. "Modernizing Bureaucrats, Backwards Africans, and the Development Concept." In International Development and the Social Sciences, edited by Frederick Cooper and Randall Packard, 64-92. Berkeley: University of California Press.

Crewe, Emma, and Elizabeth Harrison. 1998. Whose Development? An Ethnography of Aid. London: Zed Books.

Crush, Jonathan. 1995. "Imagining Development." In Power of Development, edited by Jonathan Crush, 1-26. London: Routledge.

Da Corta, Lucia, and Laurence Price. 2009. "Poverty and Growth in Remote Villages in Tanzania (2004-2008): Insights from Village Voices Film Research." CPRC Working Paper 153: 4-60.

Ellis, Stephen. 2002. "Writing Histories of Contemporary Africa." Journal of African History 
43: $1-26$.

Ergas, Zaki. 1980. "Why Did the Ujamaa Policy Fail? Towards a Global Analysis." The Journal of Modern African Studies 18 (3): 387-410.

Ferguson, James. 1999. Expectations of Modernity: Myths and Meaning of Urban Life on the Zambian Copperbelt. Berkeley: University of California Press.

2006. Global Shadows: Africa in the Neoliberal World Order. Durham, N.C.: Duke University Press.

Grace, Joshua. 2013. "Heroes of the Road: Race, Gender and the Politics of Mobility in Twentieth Century Tanzania." Africa 83 (3): 403-25.

Green, Maia. 2000. "Participatory Development and the Appropriation of Agency in Southern Tanzania." Critique of Anthropology 20 (1): 67-89.

Harrison, Graham. 2008. "From the Global to the Local? Governance and Development at the Local Level: Reflections from Tanzania." Journal of Modern African Studies 46 (2): 16989.

Havnevik, Kjell J. 1993. Tanzania: The Limits to Development From Above. Motala, Sweden: Motala Grafiska AB.

Hodge, Joseph M. 2007. Triumph of the Expert: Agrarian Doctrines of Development and the Legacies of British Colonialism. Athens: Ohio University Press.

Hodgson, Dorothy L. 2000. "Taking Stock: State Control, Ethnic Identity and Pastoralist Development in Tanganyika, 1948-1958." Journal of African History 41: 55-78.

Hunter, Emma. 2008. "Revisiting Ujamaa: Political Legitimacy and the Construction of Community in Post-Colonial Tanzania." Journal of East African Studies 2 (3): 471-85.

Jennings, Michael. 2002. “Almost an Oxfam in Itself”: Oxfam, Ujamaa and Development in Tanzania." African Affairs 101: 509-30.

2003. "We Must Run While Others Walk: Popular Participation and Development Crisis in Tanzania, 1961-69." Journal of Modern African Studies 41 (2): 163-87.

2008. Surrogates of the State: NGOs, Development, and Ujamaa in Tanzania. Bloomfield, Conn.: Kumarian Press.

Kamat, Vinay. 2008. "This Is Not Our Culture! Discourses of Nostalgia and Narratives of Health Concerns in Post-Socialist Tanzania." Africa 78 (3): 359-83.

Katz, Cindi. 2004. Growing up Global: Economic Restructuring and Children's Everyday Lives. Minneapolis: University of Minnesota Press.

Killian, Bernadeta. 2003. "Impacts of Finnish Aid in Forestry and Rural Development." Dar- 
es-Salaam: Department of Political Science, University of Dar-es-Salaam.

Klager, Gabriel. 2013. "Introduction: The Perils and Possibilities of African Roads." Africa 83 (3): $359-66$.

Kothari, Uma. 2005. "From Colonial Administration to Development Studies: A Post-Colonial Critique of the History of Development Studies." In A Radical History of Development Studies, edited by Uma Kothari, 47-66. London: Zed Books.

Lal, Priya. 2010. "Militants, Mothers, and the National Family: Ujamaa, Gender, and Rural Development in Postcolonial Tanzania." Journal of African History 51: 1-20.

2012. "Self-Reliance and the State: The Multiple Meanings of Development in Early PostColonial Tanzania." Africa 82 (2): 212-34.

Lawi, Yusufu. 2005. 'Between the 'Global' and 'Local' Families: The Missing Link in School Teaching in Postcolonial Tanzania." In In Search of a Nation: Histories of Authority and Dissidence in Tanzania, edited by Gregory H. Maddox and James L. Giblin, 290-305. Oxford: James Curry.

Maier, Karl. 1998. Into the House of the Ancestors: Inside the New Africa. New York: Wiley.

Mamdani, Mahmood. 1996. Citizen and Subject: Contemporary Africa and the Legacy of Late Colonialism. London: James Curry.

Marsland, Rebecca. 2007. "The Modern Traditional Healer: Locating 'Hybridity' in Modern Traditional Medicine, Southern Tanzania." Journal of Southern African Studies 33 (4): 751-65.

Mashindano, Oswald, et al. 2011. "Agricultural Growth and Poverty Reduction in Tanzania 2000-2010." Chronic Poverty Research Centre Working Paper 208: 1-40.

Masquelier, Adeline. 2002. "Road Mythographies: Space, Mobility, and the Historical Imagination in Postcolonial Niger.” American Ethnologist 29 (4): 829-55.

Mercer, Claire C. 2002. "The Discourse of Maendeleo and the Politics of Women's Participation on Mount Kilimanjaro.” Development and Change 33: 101-27.

Morton, Christopher. 2007. "Remembering the House: Memory and Materiality in Northern Botswana." Journal of Material Culture 12 (2): 157-79.

Myddelton, D. R. 2007. They Meant Well: Government Project Disasters. London: The Institute of Economic Affairs.

Nyerere, Julius K. 1973. Freedom and Development: A Selection from Writings and Speeches 1968-1973. Dar es Salaam: Oxford University Press. 
Piot, Charles. 2010. Nostalgia for the Future: West Africa after the Cold War. London: University of Chicago Press.

Pitcher, M. Anne, and Kelly M. Askew. 2006. “African Socialisms and Postsocialisms.” Africa $76(1): 1-14$.

Ranger, Terence. 1996. "Postscript: Colonial and Postcolonial Identities." In Postcolonial Identities in Africa, edited by Richard Werbner and Terence Ranger, 271-81. London: Zed Books.

Reef, Anne. 2008. "African Words, Academic Choices: Re-presenting Interviews and Oral Histories." History in Africa 35: 419-38.

Rizzo, Matteo. 2006. "What Was Left of the Groundnut Scheme? Development Disaster and Labour Market in Southern Tanganyika 1946-1952." Journal of Agrarian Change 6 (2): 205-38.

2009. "Becoming Wealthy: The Life-History of a Rural Entrepreneur in Tanzania, 1922-80s." Journal of Eastern African Studies 3 (2): 221-39.

Rosaldo, Renato. 1989. “Imperialist Nostalgia.” Representations 26: 107-22. Sanders,

Schneider, Leander. 2007. "High on Modernity? Explaining the Failing of Tanzanian Villagization.” African Studies 66: 9-38.

Scott, James C. 1998. Seeing Like a State: How Certain Schemes to Improve the Human Condition Have Failed. London: Yale University Press.

Seppälä, Pekka "Introduction." In The Making of a Periphery: Economic Development and Cultural Encounters in Southern Tanzania, edited by Pekka Seppälä and Bertha Koda, 736. Stockholm: Elanders Gotab AB.

Seppälä, Pekka, and Bertha Koda. 1998. The Making of a Periphery: Economic Development and Cultural Encounters in Southern Tanzania. Stockholm: Elanders Gotab AB.

Spivak, Gayatri C. 1999. A Critique of Postcolonial Reason: Toward a History of the Vanishing Present. Cambridge, Mass.: Harvard University Press.

Stewart, Kathleen. 1988. "Nostalgia: A Polemic." Cultural Anthropology 3 (3): 227-41.

Todd. 2008. "Buses in Bongoland: Seductive Analytics and the Occult." Anthropological Theory 8 (2): 107-32.

Tonkin, Elizabeth. 1992. Narrating Our Pasts: The Social Construction of Oral History. Cambridge, U.K.: Cambridge University Press.

Toohey, Peter. 2003. "The Cultural Logic of Historical Periodization." In Handbook of Historical Sociology, edited by Gerard Delanty and Engin F. Isin, 208-20. London: Sage. 
United Republic of Tanzania. 2009. Mtwara Region Village Statistics. Mtwara: Regional Government Offices.

Van Beusekom, Monica M. 2000. "Disjunctures in Theory and Practice: Making Sense of Change in Agricultural Development at the Office Du Niger 1920-1960." Journal of African History 41: 79-99.

Van Beusekom, Monica M., and Dorothy L. Hodgson. 2000. "Lessons Learned? Development Experiences in the Late Colonial Period." Journal of African History 41: 29-33.

Wembah-Rashid, J. A. R. 1998. "Is Culture in South-Eastern Tanzania Development Unfriendly?" In The Making of a Periphery: Economic Development and Cultural Encounters in Southern Tanzania, edited by Pekka Seppälä and Bertha Koda, 39-57. Stockholm: Elanders Gotab AB.

Werbner, Richard. 1998. "Introduction: Beyond Oblivion, Confronting Memory Crisis." In Memory and the Postcolony: African Anthropology and the Critique of Power, edited by Richard Werbner, 1-17. London: Zed Books.

\footnotetext{
${ }^{1}$ Wazee is the plural term used here to denote older people. While this term can infer status in Swahili, herein it is taken to mean anyone who was 65 or older at the time of the interviews in 2009-10 and 2012.

${ }^{2}$ Liberalization during the 1980s saw, among other innovations, the emergence of duka la dawa (private pharmacies), which replaced state providers and charged much higher prices.

${ }^{3}$ This perception of discrimination against the south generally allows for a couple of exceptions, such as the few improvements brought about by Benjamin Mkapa, the "southern president" (1995-2005), and, of course, the perceived advances during the handful of years of the colonial Groundnut Scheme.

${ }^{4}$ It has not been possible to detail the ways in which NGOs are seen, but similar views pervade the broader study from which this article is drawn.
} 